Jurnal Ekonomi dan Industri

e-ISSN: $2656-3169$

Volume 21, No.3, September-Desember 2020

p- ISSN: 0853-5248

\title{
PENGARUH DISIPLIN KERJA DAN KOMUNIKASI TERHADAP KINERJA KARYAWAN PT. DYANDRA PROMOSINDO
}

\author{
Rafi Elmanda ${ }^{1)}$ \\ 1) Mahasiswa Program Studi Manajemen FE UNKRIS \\ M. Reza Anwar Nurdin 2) \\ 2) Dosen Program Studi Manajemen FE UNKRIS \\ Alamat: Kampus UNKRIS, Jatiwaringin Jakarta Timur \\ Email: mreza@unkris.ac.id
}

\begin{abstract}
The purpose of this study was to determine the effect of work discipline and communication on employee performance PT. Dyandra Promosindo. The research method uses qualitative and quantitative descriptive analysis, the analysis model used is linear regression both simply and multiple. The study population of all employees of PT. Dyandra Promosindo. The sampling technique of this study used simple random sampling. This study uses a sample size with the Slovin formula. Result work discipline and communication have positive and significant effect on the employees performance of PT. Dyandra Promosindo's, both partially and simultaneous.
\end{abstract}

Keywords: Work discipline, communication and employees performance

\section{PENDAHULUAN}

Dalam kehidupan berorganisasi, faktor manusia merupakan masalah utama disetiap kegiatan yang ada didalamnya. Organisasi merupakan kesatuan sosial yang dikoordinasikan secara sadar dengan sebuah batasan yang reaktif dapat diidentifikasikan, bekerja secara terus menerus untuk mencapai tujuan (Robbins, 2008). Semua tindakan yang diambil dalam setiap kegiatan diprakarsai dan ditentukan oleh manusia yang menjadi anggota perusahaan.

Perusahaan membutuhkan adanya faktor sumber daya manusia yang potensial baik pemimpin maupun karyawan pada pola tugas dan pengawasan yang merupakan penentu tercapainya tujuan perusahaan. Agar aktivitas manajemen dapat berjalan dengan baik, maka diperlukan adanya kerjasama antara semua sumber daya manusia yang ada dalam perusahaan tersebut, baik pimpinan maupun karyawannya sehingga kinerja karyawan akan semakin meningkat.

Dalam persaingan yang semakin kompetitif, perusahaan harus tanggap menghadapi permasalahan yang terjadi baik dari lingkungan dalam perusahaan maupun luar perusahaan. Perusahaan harus menyadari pentingnya memiliki kondisi perusahaan yang kondusif yang dapat memberikan dorongan semangat pada sumber daya manusia yang bekerja didalam perusahaan untuk berusaha semaksimal mungkin mencapai misi dan tujuan perusahaan, dan kondisi perusahaan yang kondusif tersebut tercipta dari kebijaksanaan perusahaan yang dibangun dan diterapkan.

Disiplin kerja sangat penting untuk perkembangan perusahaan karena dapat dijadikan alat untuk memotivasi agar dapat mendisiplinkan diri dalam melaksanakan pekerjaan baik secara perorangan maupun kelompok. Adanya disiplin kerja dalam perusahaan akan membuat karyawan dapat menjalankan tugas-tugas yang dibebankan kepadanya dengan baik. Karyawan yang disiplin dan patuh terhadap norma-norma yang berlaku dalam 
perusahaan dapat meningkatkan produktivitas dan prestasi kerja karyawan yang bersangkutan. Dapat dipahami bahwa disiplin kerja bermanfaat mendidik karyawan untuk memenuhi peraturan, prosedur, maupun kebijakan yang ada, sehingga dapat menghasilkan kinerja yang baik. Disiplin kerja memberikan dampak suasana kerja yang menyenangkan, sehingga akan menambah semangat dalam melaksanakan pekerjaannya.

Berdasarkan data absensi karyawan PT. Dyandra Promosindo ditemukan bahwa terjadi angka peningkatan tingkat absensi karyawan yang melebihi dari batas yang telah ditentukan perusahaan dalam kurun waktu 3 (bulan) bulan terakhir sebesar $42 \%$ dan masih banyaknya angka keterlambatan karyawan datang tepat pada jam kerja. Dengan adanya peningkatan angka absensi karyawan dan banyaknya jumlah karyawan yang mengalami keterlambatan datang ini merupakan masalah yang tidak bias dibiarkan begitu saja oleh pihak perusahaan. permasalahan tersebut bisa dapat mengakibatkan menurunnya kinerja karyawan yang pada akhirnya berdampak pada tidak tercapainya target yang sudah ditetapkan oleh perusahaan.

Tabel-1: Data Absensi Karyawan PT. Dyandra Promosindo Bulan Oktober sampai Desember 2019

\begin{tabular}{cccccccc}
\hline No. & Bulan & $\begin{array}{c}\text { Jumlah } \\
\text { Karyawan }\end{array}$ & $\begin{array}{c}\text { Tidak } \\
\text { Masuk }\end{array}$ & Cuti & Izin & Jumlah & \% \\
\hline 1 & Oktober & 170 & 7 & 8 & 4 & $\mathbf{1 9}$ & $\mathbf{0 . 1 1}$ \\
2 & Nopember & 170 & 9 & 9 & 6 & $\mathbf{2 4}$ & $\mathbf{0 . 1 4}$ \\
3 & Desember & 170 & 12 & 11 & 6 & $\mathbf{2 9}$ & $\mathbf{0 . 1 7}$ \\
\hline & Jumlah & & $\mathbf{2 8}$ & $\mathbf{2 8}$ & $\mathbf{1 6}$ & $\mathbf{7 2}$ & $\mathbf{0 . 4 2}$ \\
\hline
\end{tabular}

Sumber: PT. Dyandra Promosindo, 2019

Selain disiplin kerja, faktor lain yang dapat mempengaruhi kinerja karyawan adalah komunikasi antar atasan dengan bawahan maupun antar sesama rekan kerja. Dalam melaksanakan aktivitas sehari-hari perlu adanya komunikasi, dengan tujuan untuk mengantisipasi masalah-masalah yang dihadapi oleh suatu organisasi yang pada akhirnya akan merugikan baik secara moril maupun materil karyawan serta kelangsungan hidup perusahaan.

Manusia pada hakekatnya adalah mahkluk sosial, yang dalam kehidupan sehari- hari tidak bisa lepas dari kegiatan interaksi dan komunikasi. Komunikasi merupakan bagian integral kehidupan manusia, apapun statusnya di masyarakat. Sebagai mahkluk sosial, kegiatan sehari- hari selalu berhubungan dengan orang lain dalam upaya pemenuhan kebutuhan hidup.

PT. Dyandra Promosindo adalah professional exhibition organizer terdepan di Indonesia yang telah berdiri sejak tahun 1994. PT. Dyandra Promosindo adalah penyelenggara pameran profesional terkemuka, didirikan sejak 1994. Selama bertahuntahun, PT. Dyandra Promosindo telah menghasilkan rekam jejak yang mengesankan dari berbagai acara di seluruh negeri. Selama beberapa tahun terakhir, PT. Dyandra Promosindo telah menyelenggarakan lebih dari 800 pameran di Jakarta, Surabaya, Yogyakarta, Bali, Makassar, Medan dan kota-kota besar lainnya di Indonesia. Dengan lebih dari 1.000 peserta pameran setiap tahun, termasuk peserta asing, PT. Dyandra Promosindo telah membuktikan diri sebagai mitra bisnis yang dapat diandalkan sembari memajukan budaya budaya pameran yang sepenuhnya baru di Indonesia. Berbagai pameran kami meliputi pameran dagang, pameran konsumen, konferensi, dan konferensi tingkat tinggi. PT. Dyandra Promosindo, sub holding dari PT. Dyandra Media International, Tbk, yang juga 
adalah bagian dari Kompas Gramedia, merupakan perusahaan exhibition organizer pertama yang berhasil meraih ISO 9001, 2008.

Berdasarkan pengamatan, ada dua hal yang menjadi perhatian bagi PT. Dyandra Promosindo, yaitu disiplin kerja yang masih relatif kurang diperhatikan oleh para karyawan dan juga komunikasi sesama rekan kerja yang belum berjalan sebagaimana mestinya. Upaya-upaya untuk meningkatkan kinerja karyawan merupakan tantangan PT. Dyandra Promosindo. Untuk mencapai tujuan dan kelangsungan hidup PT. Dyandra Promosindo tergantung pada kualitas kinerja sumber daya manusia yang ada di dalamnya. Kinerja PT. Dyandra Promosindo, akan sangat ditentukan oleh unsur karyawannya. Dalam mengukur kinerja PT. Dyandra Promosindo, sebaiknya diukur dalam tampilan kerja dari karyawannya.

Tujuan penelitian ini adalah untuk menganalisis pengaruh disiplin kerja dan komunikasi terhadap kinerja karyawan PT. Dyandra Promosindo.

\section{LANDASAN TEORI}

\section{Kinerja}

Kinerja karyawan merupakan hasil kerja secara kualitas dan kuantitas yang dicapai oleh seorang karyawan dalam melaksanakan fungsinya sesuai dengan tanggung jawab yang diberikan kepadanya. Kinerja karyawan menurut Dessler (2010) merupakan prestasi kerja yaitu "perbandingan antara hasil kerja dengan standar yang ditetapkan". Kinerja merupakan aktivitas manusia yang diarahkan pada pelaksanaan tugas organisasi yang diberikan kepadanya. Menurut Mangkunegara (2015), kinerja (prestasi kerja) adalah "hasil kerja secara kualitas dan kuantitas yang dicapai oleh seorang pegawai dalam melaksanakan tugasnya sesuai gengan tanggung jawab yang diberikan kepadanya”. Menurut Hasibuan (2013), kinerja merupakan "suatu hasil kerja yang dicapai seseorang dalam melaksanakan tugasnya atau kecakapan usaha dan kesempatan". Kinerja adalah "hasil kerja yang dicapai oleh seseorang atau kelompok orang dalam suatu organisasi, sesuai dengan wewenang dan tanggjung jawab masing-masing dalam rangka upaya mencapai tujuan organisasi bersangkutan, secara legal tidak melanggar hukum dan sesuai dengan moral maupun etika" (Mathis dan Jackson, 2006).

Berdasarkan paparan tersebut, kinerja adalah suatu hasil yang di capai seseorang dalam melaksanakan tugas-tugas yang didasarkan atas kecakapan, pengalaman dan kesungguhan serta waktu menurut standar dan kriteria yang telah ditetapkan sebelumnya. Jadi, kinerja adalah suatu hasil yang dicapai seseorang dalam melaksanakan tugas-tugas yang didasarkan atas kecakapan, pengalaman, dan kesungguhan serta waktu menurut standar.

Begitu pentingnya masalah kinerja karyawan ini, sehingga tidak salah bila inti pengelolaan sumber daya manusia adalah bagaimana mengelola kinerja sumber daya manusia. Mengelola manusia dalam konteks organisasi berarti mengelola manusia agar dapat menghasilkan kinerja yang optimal bagi organisasi. Oleh karena itu, kinerja pegawai ini perlu dikelola secara baik untuk mencapai tujuan organisasi sehingga menjadi suatu konsep manajemen kinerja.

Di sebagian besar organisasi, kinerja karyawan individual merupakan faktor utama yang menentukan keberhasilan organisasi. Faktor yang mempengaruhi kinerja karyawan individual (Mathis dan Jackson, 2006) yaitu: 1) "Kemampuan individual, terdiri dari beberapa komponen yaitu bakat, minat dan faktor kepribadian. 2) Usaha yang dicurahkan yaitu terdiri dari motivasi, etika kerja, kehadiran dan rancangan tugas. 3) Dukungan 
organisasi yang diterimanya terdiri dari pelatihan dan pengembangan, peralatan dan teknologi, standar kinerja, manajemen dan rekan kerja".

Ada enam katagori yang digunakan untuk mengukur tingkat kinerja karyawan secara individual (Dessler, 2010) sebagai berikut: 1) "Quality, yaitu tingkat dimana hasil kerja dari karyawan yang dilakukan mendekati sempurna dalam arti ketepatan, ketelitian, dan dapat diterima dari suatu aktivitas. 2) Produkctivity, yaitu kuantitas atau jumlah yang dihasilkan secara efisien dan efektif. 3) Job khowlwdge, yaitu tingkat pengetahuan yang dimiliki oleh seorang karyawan atapun informai yang dimiliki untuk menyelesaikan pekerjaan. 4) Reliability, yaitu tingkat dimana seorang karyawan dapat dipercaya selama menyelesaikan pekerjaan dalam hal tindak lanjut pekerjaan. 5) Availability, yaitu tingkat ketepatan waktu dari suatu aktivitas yang diselesaikan oleh karyawan dan ketepatan dalam catatan daftar kehadiran karyawan. 6) Independence, yaitu tingkat dimana seorang karyawan dapat melakukan pekerjaannya tanpa bantuan bimbingan dari pengawasnya".

Menurut Robbins, (2008), indikator untuk mengukur kinerja karyawan secara individu ada enam indikator: 1) "Kualitas; Kualitas kerja diukur dari persepsi karyawan terhadap kualitas pekerjaan yang dihasilkan serta kesempurnaan tugas terhadap keterampilan dan kemampuan karyawan. 2) Kuantitas; Merupakan jumlah yang dihasilkan dinyatakan dalam istilah seperti jumlah unit, jumlah siklus aktivitas yang diselesaikan. 3) Ketepatan waktu; Merupakan tingkat aktivitas diselesaikan pada awal waktu yang dinyatakan, dilihat dari sudut koordinasi dengan hasil output serta memaksimalkan waktu yang ada untuk aktifitas lain. 4) Efektifitas; Merupakan tingkat penggunaan sumber daya organisasi (tenaga, uang, teknologi, bahan baku) dimaksimalkan dengan maksud manaikkan hasil dari setiap unit dalam penggunaan sumber daya. 5) Kemandirian; Merupakan tingkat seorang karyawan yang nantinya akan menjalankan fungsi kerjanya komitmen kerja. Merupakan suatu tingkat dimana karyawan mempunyai komitmen kerja dengan instansi dan tanggung jawab karyawan terhadap perusahaan. 6) Komitmen kerja; Merupakan suatu tingkat dimana karyawan mempunyai komitmen kerja dengan instansi dan tanggung jawab karyawan terhadap kantor".

\section{Disiplin Kerja}

Disiplin merupakan "suatu kekuatan yang berkembang di dalam tubuh pekerja sendiri yang menyebabkan dia dapat menyesuaikan diri dengan sukarela kepada keputusan-keputusan, peraturan-peraturan, dan nilai-nilai tinggi dari pekerjaan dan tingkah laku" (Asmiarsih, 2006). Menurut Fathoni (2006), kedisiplinan adalah "kesadaran dan kesediaan seseorang menaati semua peraturan perusahaan dan norma-norma sosial yang berlaku”. Kedisiplinan dapat diartikan bilamana karyawan selalu datang dan pulang tepat pada waktunya, mengerjakan semua pekerjaannya dengan baik, mematuhi semua peraturan perusahaan dan norma-norma sosial yang berlaku. Kedisiplinan harus ditegakkan dalam suatu organisasi perusahaan, karena tanpa dukungan disiplin karyawan yang baik maka sulit perusahaan untuk mewujudkan tujuannya. Kemudian menurut Hasibuan (dalam Barnawi, 2012), disiplin kerja adalah "kemampuan kerja seseorang untuk secara teratur, tekun, terus menerus, dan bekerja sesuai dengan aturan-aturan yang berlaku dengan tidak melanggar aturan-aturan yang sudah ditetapkan". Rivai, (2015), mengemukakan disiplin kerja adalah "suatu alat yang digunakan para manajer untuk berkomunikasi dengan karyawan agar mereka bersedia untuk mengubah suatu perilaku serta sebagai suatu upaya untuk meningkatkan kesadaran dan kesediaan seseorang untuk mentaati semua peraturan perusahaan dan norma-norma sosial yang berlaku". 
Berdasarkan pendapat tersebut, dapat disimpulkan bahwa disiplin kerja karyawan merupakan sikap atau tingkah laku yang menunjukkan kesetiaan dan ketaatan seseorang atau sekelompok orang terhadap peraturan yang telah ditetapkan oleh instansi atau organisasinya baik yang tertulis maupun tidak tertulis sehingga diharapkan pekerjaan yang dilakukan efektif dan efesien.

Rasa kepedulian karyawan yang tinggi sangat mempengaruhi pencapaian tujuan yang akan meningkatkan kedisiplinan bagi karyawan, serta dalam semangat yang tinggi dalam melakukan pekerjaan dan membangkitkan gairah kerja yang tinggi dan untuk meningkatkan inisiatif dalam pencapaian tujuan. manfaat penerapan disiplin kerja baik pada pegawai dalam upaya mencapai disiplin kerja dikemukakan oleh Saydam (2010). Manfaat dari penerapan disiplin kerja yang akan terlihat pada: 1) "Tingginya rasa kepedulian karyawan terhadap pencapaian tujuan perusahaan. 2) Tingginya semangat dan gairah kerja para karyawan dalam melakukan pekerjaannya. 3) Berkembangnya rasa memiliki dan kesetiakawanan yang tinggi di kalangan karyawan. 4) Besarnya tanggung jawab para karyawan melaksanakan tugas dengan sebaik-baiknya. 5) Meningkatnya efisiensi dan produktivitas para karyawan”.

Disiplin kerja dipengaruhi oleh sejumlah faktor dari dalam maupun dari luar diri karyawan. Faktor dari dalam adalah persepsi terkait dengan peraturan tersebut. Peraturan dibuat untuk mencapai tujuan. Singodimedjo (dalam Barnawi 2012) menyatakan tujuh faktor eksternal yang mempengaruhi disiplin karyawan yaitu: 1) "Kompensasi; Besar atau kecilnya kompensasi dapat dapat mempengaruhi displin kerja. Karyawan cenderung akan mematuhi segala peraturan apabila ia merasa kerja kerasnya akan mendapatkan imbalan yang sesuai dengan jerih payah yang diberikan oleh pimpinan, apabila para guru atau karyawan memperoleh kompensasi memadai, mereka akan bekerja dengan tekun disertai dengan perasaan senang. 2) Keteladanan pimpinan; Keteladanan pimpinan sangat dibutuhkan oleh setiap bawahan diorganisasi manapun. Pemimpin adalah panutan. Ia merupakan tempat bersandar bagi para bawahannya. Pemimpin yang bisa menjadi teladan akan mudah menerapkan disiplin kerja bagi karyawannya. Demikian pula sebaliknya, pemimpin yang buruk akan sulit mengadakan disiplin kerja bagi para bawahannya. Oleh karena itu, pimpinan harus dapat menjadi contoh bagi para bawahannya jika mengiginkan disiplin kerja yang sesuai dengan harapan. 3) Aturan yang pasti; Didiplin kerja tidak akan terwujud tanpa acanya aturan pasti yang dapat menjadi pedoman bagi bawahan dalam menjalankan tugasnya. Aturan yang tidak jelas kepastiannya tidak akan mungkin bisa terwujud dalam perilaku bawahan. Setiap bawahan tidak akan percaya pada aturan yang berubah-ubah dan tidak jelas kepastiannya. Aturan yang pasti ialah aturan yang dibuat tertulis yang dapat menjdi pedoman bagi karyawan dan tidak berubah-ubah karena situasi dan kondisi. 4) Keberanian pimpinan dalam mengambil tindakan; Apabila terdapat pelanggaran disiplin kerja, pimpinan harus memiliki keberanian untuk menyikapi sesuai dengan aturan yang menjdi pedoman bersama. Pimpinan tidak boleh bertindak diskriminasi dalam menagani pelanggaran disiplin kerja. 5) Pengawasan pemimpin; Pengawasan sangat diperlukan untuk memastikan segala kegiatan berjalan sesuai dengan standar peraturan. Pengawasan yang lemah memberi kesempatan bawahan melanggar peraturan. Pengawasan sangat penting mengingat sifat dasar yang ingin bebas tanpa terikat oleh aturan. 6) Perhatian kepada para karyawan; Karyawan tidak hanya membutuhkan kompensasi yang besar, tetapi perlu juga perhatian dari atasannya. Kesulitan-kesulitan yang dihadap pagawai ingin didengar dan selanjutnya diberikan masukan oleh pimpinan, pimpinan yang suka memberika perhatian kepada karyawannya akan menciptakan kehangatan hubungan kerja antara atasan dengan bawahannya .pimpinan yang semacam itu 
akan dihormati dan dihargai oleh para bawahannya. Karyawan yang segan dan hormat kepada pimpinan akan memiliki disiplin kerja yang sesungguhnya. Yaitu, disiplin kerja yang penuh kesadaran dan kerelaan dalam menjalaninya. 7) Kebiasaan-kebiasaan yang mendukung tegaknya disiplin; Kebiasaan-kebiasaan positif itu, diantaranya a) Mengucapkan salam dan berjabat tangan apabila bertemu; b) Saling menghargai antar sesama rekan; c) Saling memperhatikan antar sesama rekan; d) Memberitahu saat meninggalkan tempat kerja kepada rekan".

Pada dasarnya, banyak indikator yang mempengaruhi tingkat kedisiplinan karyawan suatu perusahaan, diantaranya yang disampaikan oleh Moenir (2014) mengenai indikator yang mempengaruhi disiplin kerja, yaitu; 1). "Ketepatan waktu; Ketepatan waktu dalam pekerjaan dan tugas, meliputi: a) Ketepatan waktu dalam melaksanakan tugas. b) Penghematan waktu dalam melaksanakan tugas. 2) Tanggung Jawab; Tanggungjawab dalam pekerjaan dan tugas, meliputi: a) Melakukan pekerjaan sesuai dengan rencana. b) Mengevaluasi hasil pekerjaan. c) Keberanian menerima resiko kesalahan. 3) Ketaatan; Ketaatan terhadap peraturan yang telah ditetapkan, meliputi: a) Ketaatan terhadap jam kerja. b). Ketaatan terhadap pimpinan. dan c). Ketaatan terhadap prosedur dan metode kerja".

\section{Komunikasi}

Pengertian komunikasi dapat dimaknai sebagai jalannya proses, dimana seseorang maupun sekelompok orang menciptakan serta menggunakan sejumlah informasi agar saling terhubung dengan lingkungan sekitar. Secara umum komunikasi dapat dilakukan secara verbal serta dapat dipahami oleh kedua belah pihak berkaitan.

Komunikasi merupakan suatu proses upaya membangun pengertian antara yang satu dengan yang lainnya, agar terjadi kesamaan pemahaman mengenai suatu hal, dengan komunikasi yang baik dan lancar diharapkan semua aktivitas yang dikerjakan dapat berjalan sesuai dengan tujuan perusahaan yang sudah ditatapkan. Menurut Jenis dan Kelly, "komunikasi adalah suatu proses melalui mana seseorang (komunikator) menyampaikan stimulus (biasanya dalam bentuk kata-kata) dengan tujuan mengubah atau membentuk perilaku orang lainnya (khalayak)" (Vardiansyah, 2008). Menurut Stoner (2006), komunikasi adalah "rangkaian langkah serah terima maksud yang terjadi dengan dinamis serta konstan berubah sesuai dengankondisi yang berlaku". Pendapat Schemerhorn, et al, yang dikutip oleh Widjaja (2000), komunikasi itu dapat diartikan sebagai: "proses antar pribadi dalam mengirim dan menerima simbol-simbol yang berarti bagi kepentingan mereka ". Menurut Arifin (2015), komunikasi adalah "sebuah proses yang kaya makna". Hal ini dikarenakan komunikasi dapat dipetakan dengan menempatkan komunikasi sebagai proses sosial yang terdapat dalam konteks ilmu sosial. Disini, para ahli dari bidang ilmu sosial melakukan riset menggunakan pendekatan komunikasi yang secara general berfokus pada satu titik, yaitu aktivitas manusia serta keterlibatan pesan dan tindakan yang dilakukan.

Komunikasi tidak hanya sekedar proses penyampaian informasi yang simbolsimbolnya dapat dilihat, didengar dan dimengerti, tetapi proses penyampaian informasi secara keseluruhan termasuk di dalamnya perasaan dan sikap dari orang yang menyampaikannya. Pada umumnya, seseorang menangkap hanya informasinya saja, dan dilupakan bagaimana perasaan dan sikap orang yang mempunyai informasi tersebut.

Menurut Nugroho (2004) tujuan komunikasi adalah "menciptakan pemahaman bersama atau mengubah persepsi, bahkan perilaku". Dengan demikian komunikasi mempunyai peranan yang sangat penting dalam menentukan betapa efektifnya orang-orang 
bekerja sama dan mengkoordinasikan usaha-usaha untuk mencapai tujuan. Pada umumnya, tujuan komunikasi antara lain menurut Widjaja, (2000), yaitu: 1) "Supaya yang kita sampaikan dapat mengerti, sebagai komunikator kita harus menjelaskan kepada komunikan (penerima) dengan sebaik-baiknya dan tuntas, sehingga mereka dapat mengerti dan mengakui apa yang kita maksud. 2) Memahami orang lain. komunikator harus mengerti benar aspirasi masyarakat tentang apa yang diinginkan kemauannya. 3) Supaya gagasan dapat diterima orang lain. Komuikator berusaha agar gagasan dapat diterima orang lain dengan pendekatan persuasive, bukan memaksakan kehendak. 4) Menggerakkan orang lain untuk melakukan sesuatu, menggerakan sesuatu itu dapat bermacam-macam, mungkin berupa kegiatan. Kegiatan dimaksud di sini adalah kegiatan yang lebih banyak mendorong, namun yang penting harus diingat adalah bagaimana cara baik untuk melakukan".

Macam-macam komunikasi adalah sebagai berikut: 1) Komunikasi berdasarkan cara penyampaiannya terdiri dari dua yaitu komunikasi verbal dan komunikasi tertulis. 2) Komunikasi berdasarkan maksud. Contohnya seperti komunikasi pidato, pemberian saran atau trik, memberikan perintah, memberikan ceramah dan wawancara. 3) Komunikasi berdasarkan ruang lingkup ada dua, yaitu komunikasi internal dan komunikasi eksternal. 4) Komunikasi berdasarkan aliran informasi.

Menurut Uchjana: (2006), indikator-indikator komunikasi dapat diukur dengan:

1) Komunikasi sesama karyawan. 2) Komunikasi dengan karyawan bagian lain.

3) Komunikasi antar sesama kepala bagian. 4) Koordinasi pimpinan dengan karyawan.

5). Koordinasi antar sesama karyawan.

\section{METODE PENELITIAN}

Penelitian ini dengan menggunakan analisis deskriptif kualitatif dan kuantitaf, model analisis yang digunakan regresi linear baik secara sederhana maupun berganda. Populasi penelitian adalah seluruh karyawan PT Dyandra Promosindo yang berjumlah 170 orang karyawan. Teknik sampling penelitian ini menggunakan simple random sampling. Penelitian ini menggunakan ukuran sampel dengan rumus Slovin dan didapat sebanyak 63 responden

\section{HASIL PENELITIAN DAN PEMBAHASAN}

\section{Hasil Penelitian}

\section{Hasil uji validitas dan uji reliabilitas}

Variabel penelitian yang terdiri dari disiplin kerja, komunikasi, dan kinerja keseluruhan memiliki 39 butir pernyataan. Validitas merupakan derajat ketepatan antara data yang terjadi pada objek penelitian dengan data yang dapat dilaporkan oleh peneliti. Pada uji validitas digunakan untuk mengukur yang dapat dikatakan sah atau tidaknya suatu kuesioner (Sugiyono, 2016). Berdasarkan uji validitas terdapat 9 butir pertanyaan untuk disiplin kerja, 10 butir pertanyaan untuk komunikasi, 10 pertanyaan butir untuk kinerja dengan hasilnya dinyatakan valid.

Pengujian reliabilitas diperlukan untuk menguji seberapa jauh hasil pengukuran yang dapat diandalkan secara konsisten. Pada tabel-2, hasil pengujian reliabilitas menunjukkan bahwa nilai Cronbach's Alpha semua variabel dalam penelitian ini lebih besar dari 0,6, sehingga penelitian ini dapat dianggap reliabel. 
Tabel-2: Hasil Uji Reliabilitas

\begin{tabular}{lccc}
\hline \multicolumn{1}{c}{ Variabel } & $\begin{array}{c}\text { Cronbach } \\
\text { Alpha }\end{array}$ & $\begin{array}{c}\text { Nilai kritis } \\
(\boldsymbol{\alpha})=\mathbf{5 \%}\end{array}$ & Keterangan \\
\hline Disiplin Kerja & 0.718 & 0.600 & Reliabel \\
Komunikasi & 0.706 & 0.600 & Reliabel \\
Kinerja Karyawan & 0.725 & 0.600 & Reliabel \\
\hline
\end{tabular}

Sumber: Data Primer, diolah tahun 2020

\section{Hasil analisis regresi linear sederhana}

Tabel-3: Pengaruh Disiplin Kerja terhadap Kinerja Karyawan

\begin{tabular}{lccccc}
\hline \multirow{2}{*}{ Variabel } & R-Square & Konstanta & $\begin{array}{c}\text { Koefisien } \\
\text { Regresi }\end{array}$ & Sig & $\boldsymbol{\alpha}$ \\
\cline { 2 - 6 } & 0,713 & 7,348 & 0,918 & 0,000 & 0,05 \\
\hline Disiplin_kerja & t-hitung > t-tabel $=12,314>2,000$ & & & \\
\hline Sumber: Data primer, diolah 2020
\end{tabular}

Persamaan regresi $\mathrm{Y}=7,348+0,918 \mathrm{X}_{1}$

Berdasarkan tabel-3, nilai koefisien determinasi $\left(\mathrm{R}^{2}\right)$ sebesar 0.713 , artinya disiplin kerja memberikan kontribusi sebesar $71,3 \%$ kepada kinerja karyawan PT. Dyandra Promosindo, sedangkan sisanya sebesar $28,7 \%$ disumbangkan faktor lain yang tidak diteliti. Disiplin kerja berpengaruh positif terhadap kinerja karyawan PT. Dyandra Promosindo dengan koefisien sebesar 0,918, artinya jika ada peningkatan disiplin kerja, maka kinerja karyawan PT. Dyandra Promosindo akan meningkat atau sebaliknya. Nilai t-hitung lebih besar dari t-tabel $(12,314>2,000)$, maka Ho tolak, Ha terima, artinya disiplin kerja berpengaruh signifikan pada tingkat nyata 99\% terhadap kinerja karyawan PT. Dyandra Promosindo.

Tabel-4: Pengaruh Komunikasi terhadap Kinerja Karyawan

\begin{tabular}{lccccc}
\hline \multirow{2}{*}{ Variabel } & R-Square & Konstanta & $\begin{array}{c}\text { Koefisien } \\
\text { Regresi }\end{array}$ & Sig & $\boldsymbol{\alpha}$ \\
\cline { 2 - 6 } & 0,677 & 3,936 & 0,902 & 0,000 & 0.05 \\
\hline Komunikasi & t-hitung > t-tabel $=11,307>2,000$ & & & \\
\hline Sumber: Data primer, diolah 2020
\end{tabular}

Persamaan regresi $\mathrm{Y}=3,936+0,902 \mathrm{X}_{2}$

Berdasarkan tabel-4, nilai koefisien determinasi $\left(\mathrm{R}^{2}\right)$ sebesar 0.677, artinya komunikasi memberikan kontribusi sebesar 67,7\% kepada kinerja karyawan PT. Dyandra 
Promosindo, sedangkan sisanya sebesar 32,3\% disumbangkan faktor lain yang tidak diteliti. Komunikasi berpengaruh positif terhadap kinerja karyawan PT. Dyandra Promosindo dengan koefisien sebesar 0,902, artinya jika ada peningkatan komunikasi, maka kinerja karyawan PT. Dyandra Promosindo akan meningkat atau sebaliknya. Nilai t-hitung lebih besar t-tabel $(11.307>2,000)$, Ho tolak, Ha terima, artinya komunikasi berpengaruh signifikan pada tingkat nyata 99\% terhadap kinerja karyawan PT. Dyandra Promosindo.

\section{Hasil analisis regresi linear berganda}

Tabel-5: Pengaruh Disiplin Kerja dan Komunikasi terhadap Kinerja Karyawan

\begin{tabular}{lccccc}
\hline \multirow{1}{*}{ Variabel } & R-Square & Konstanta & $\begin{array}{c}\text { Koefisien } \\
\text { Regresi }\end{array}$ & Sig. & $\boldsymbol{\alpha}$ \\
\cline { 2 - 6 } & \multirow{2}{*}{0,749} & 0,888 & 0,565 & 0,000 & \multirow{2}{*}{$5 \%$} \\
\hline Disiplin_Kerja & & 0,474 & 0,000 & \\
Komunikasi & & & & 0,000 & \\
\hline F-hitung = 115,891 & & & & \\
\hline Sumber: Data primer, diolah 2020 & &
\end{tabular}

Persamaan regresi; $\mathrm{Y}=0,888+0,565 \mathrm{X}_{1}+0,474 \mathrm{X}_{2}$

Berdasarkan tabel-5, nilai F-hitung lebih besar dari F-tabel $(115,891>3,150)$, Ho tolak, Ha terima, artinya disiplin kerja dan komunikasi secara bersama-sama berpengaruh signifikan pada tingkat nyata 99\% terhadap kinerja karyawan PT. Dyandra Promosindo. Nilai koefisien determinasi $\left(\mathrm{R}^{2}\right)$ sebesar 0.749 , artinya disiplin kerja dan komunikasi secara bersama-sama memberikan kontribusi sebesar 74,9\% kepada kinerja karyawan PT. Dyandra Promosindo, sedangkan sisanya sebesar 25,1\% disumbangkan faktor lain yang tidak dibahas dalam penelitian ini.

Disiplin kerja dan komunikasi berpengaruh positif dan signifikan terhadap kinerja karyawan PT. Dyandra Promosindo pada tingkat nyata 99\%. Koefisien disiplin kerja sebesar 0,565, artinya jika ada peningkatan disiplin kerja, maka kinerja karyawan PT. Dyandra Promosindo akan meningkat atau sebaliknya dengan asumsi komunikasi tidak berubah. Koefisien komunikasi sebesar 0,474, artinya jika ada peningkatan komunikasi, maka kinerja karyawan PT. Dyandra Promosindo akan meningkat atau sebaliknya, dengan asumsi disiplin kerja tidak berubah.

\section{Pembahasan}

\section{Pengaruh Disiplin Kerja terhadap Kinerja Karyawan PT. Dyandra Promosindo}

Disiplin kerja yang tinggi dapat mendorong peningkatan kinerja karyawan. Hal ini dikarenakan karyawan tepat waktu dalam melaksanakan tugas, menghemat waktu dalam bekerja, bekerja sesuai selama waktu jam kerja, pekerjaan dikerjakan sesuai rencana, diminta mengevalasi hasil kerja, berani menerima resiko atas kesalahnnya, mengikuti aturan jam kerja yang berlaku, patuh atas perintah pimpinan dan mengikuti semua peraturan yang telah ditetapkan. Hasil penelitian ini sesuai dengan penelitian yang dilakukan oleh Pangarso dam Susanti, (2016) dan Thabroni, (2016), yaitu menganalisis pengaruh disiplin kerja terhadap kinerja karyawan. 


\section{Pengaruh Komunikasi terhadap Kinerja Karyawan PT. Dyandra Promosindo}

Komunikasi yang baik dapat mendorong peningkatan kinerja karyawan. Hal ini dikarenakan sesama karyawan menjalin hubungan kerja yang baik, saling membantu apabila ada kesulitan, berkomunikasi dengan bagian lain, menjaga hubungan kerja dengan bagian yang lain, sesama kepala bagian selalu berkoordinasi dalam pekerjaan, menjalin hubungan dengan baik, pimpinan memberikan petunjuk kerja pada karyawan, selalu memberikan motivasi kerja, sesama karyawan melakukan koordinasi dalam bekerja dan saling mengingatkan dalam bekerja. Hasil penelitian ini sejalan dengan penelitian yang dilakukan oleh Wandi, et al (2019) dan Kuncorowati dan Rokhmawati, (2018). yaitu menganalisis pengaruh komunikasi terhadap kinerja karyawan.

\section{Pengaruh Disiplin Kerja dan Komunikasi terhadap Kinerja Karyawan PT. Dyandra Promosindo}

Disiplin kerja yang tinggi dan komunikasai yang baik dapat mendorong peningkatan kinerja karyawan PT. Dyandra Promosindo. Hasil penelitian ini sama dengan hasil penelitian yang dilakukan oleh Novianti dan Mitariani, (2017), Ginting, (2018), dan Sihombing, et al, (2016), yaitu menganalisis pengaruh disiplin kerja dan komunikasi terhadap kinerja karyawan.

\section{KESIMPULAN DAN SARAN}

\section{Kesimpulan}

Kesimpulan dalam penelitian ini adalah sebagai berikut: 1) Disiplin kerja dapat mendorong peningkatan kinerja karyawan PT. Dyandra Promosindo. 2) Komunikasi dapat mendorong peningkatan kinerja karyawan PT. Dyandra Promosindo. 3). Disiplin kerja dan komunikasi secara bersama-sama dapat mendorong peningkatan kinerja karyawan PT. Dyandra Promosindo.

\section{Saran}

Saran-saran dalam penelitian ini adalah sebagai berikut: 1) Disiplin kerja karyawan sudah relatif baik, karyawan hadir sesuai dengan waktu yang ditetapkan, tanggung jawab terhadap pekerjaan dapat dipercaya, ketaatan mengikuti aturan dan patuh terhadap perintah pimpinan, ini semua dilaksanakan dengan baik. Sebagai masukan kiranya perusahaan melalui pimpinan terus lebih mengawasi aktifitas karyawan dan selalu berikan arahanarahan yang dapat meningkatkan kinerja karyawan. 2) Komunikasi sangat berpengaruh terhadap kinerja karyawan, oleh karena itu perusahaan lebih memperhatikan komunikasi yang telah diterapkan oleh perusahaan dan pimpinan lebih sering mengajak bawahan untuk lebih aktif dalam berkomunikasi terutama berkaitan dengan pekerjaan. 3) Bagi penelitian selanjutnya disarankan untuk menambah variabel-variabel lain yang lebih beragam dalam membahas yang berkaitan dengan kinerja karyawan dalam perusahaan yang bergerak dibidang exhibition organizer.

\section{DAFTAR PUSTAKA}

Asmiarsih, Tety. 2006. Pengaruh Pengawasan terhadap Disiplin Kerja Pegawai Kantor Badan Kepegawaian Daerah Brebes. Fakultas Ilmu Sosial Universitas Semarang. Arifin, Anwar, 2015. Strategi Komunikasi: Suatu Pengantar Ringkas, Bandung. Armico. 
Barnawi, dan Mohammad Arifin. 2012. Etika dan Profesi Kependidikan. Yogyakarta. ArRuzz Media.

Dessler, Gary. 2010. Manajemen Sumber Daya Manusia. Jakarta. PT. Indeks.

Fathoni, Abdurrahmat. 2006. Manajemen Sumber Daya Manusia. Bandung: Rineka Cipta.

Ginting, Nurmaidah Br. 2018, Pengaruh Disiplin Kerja dan Komunikasi terhadap Kinerja Karyawan di PT. Sekar Mulia Abadi Medan". AJIE - Asian Journal of Innovation and Entrepreneurship, (e-ISSN: 2477-0574; p-ISSN: 2477-3824), Volume 03, Issue. 02, May 2018. Pp. 140-139.

Hasibuan, Malayu S. P. 2013. Manajemen Sumber Daya Manusia. Jakarta. PT. Bumi Aksara.

Kuncorowati, Heru dan Rokhmawati, Heru Noor. 2018., The Influence of Communication and Work Discipline on the Employee Performance" (A Case Study of Employee Performance of Dwi Arsa Citra Persada Foundation in Yogyakarta, Indonesia). International Refereed Journal, E-ISSN 2229-4686; ISSN 2231-4172. Vol. - IX, Issue-2, April 2018. 6-13.

Mangkunegara, Anwar Prabu. 2015. Manajemen Sumber Daya Manusia Perusahaan. Bandung. Remaja Rosda Karya.

Mathis, R.L. dan J.H. Jackson. 2006. Human Resource Management: Manajemen Sumber Daya Manusia. Terjemahan Dian Angelia. Jakarta. Salemba Empat.

Moenir, H.A.S. 2014. Manajemen Pelayanan Umum di Indonesia. Jakarta. Bumi Aksara.

Novianti, Kadek dan Mitariani, Ni Wayan Eka. 2017. Pengaruh Disiplin Kerja dan Komunikasi Terhadap Kinerja Karyawan Pada De Bakker Bakery Denpasar. Jurnal Ilmu Manajemen. Vol. 7, No. 2. 2017.

Nugroho D, Riant. 2004. Kebijakan Publik, Formulasi, Implementasi, dan Evaluasi. Jakarta. Gramedia.

Pangarso, Astadi dan Susanti, Putri Intan. 2016. Pengaruh Disiplin Kerja Terhadap Kinerja Pegawai di Biro Pelayanan Sosial Dasar Sekretariat Daerah Provinsi jawa Barat. Jurnal Manajemen Teori dan Terapan. Tahun 9 No. 2, Agustus 2016. Hal. 145-160.

Rivai, Veithzal ZS. 2015. Manajemen Sumber Daya Manusia Untuk Perusahaan. Edisike7. Depok. PT Rajagrafindo.

Robbins, Stephen P. 2008. Perilaku Organisasi. Indonesia: Konsep Kontroversi, Aplikasi, Alih Bahasa: Hadayana Pujaatmaka. Jakarta. Prehalindu.

Saydam, Gauzali. 2010. Manajemen Sumber Daya Manusia. Jakarta. PT. Djambatan.

Schermerhorn, John D., Jemas G Hunt, \& Richard N., Osborn, 2005, Organizational Behaviour, John Willey and Son Inc.

Singodimedjo, Markum. 2010. Manajemen Sumber Daya Manusia. Surabaya. Penerbit SMMA.

Stoner, A.F. 2006. Manajemen Sumber Daya Manusia. Jakarta. Bumi Aksara.

Sugiyono. 2016. Statikstika Untuk Penelitian. Bandung. Alfabeta.

Thabroni, Imam. 2016. Pengaruh Disiplin Kerja dan Komunikasi terhadap Kinerja Karyawan di AHASS Setia Motor Group Kediri. JMK. Vol. 1, No. 3. Edisi September 2016: 223-234.

Uchjana, Efendy Onong. 2006. Ilmu Komunikasi Teori dan Praktek. Bandung. Remaja Rosda Karya.

Vardiansyah, Dani. 2008. Filsafat Ilmu Komunikasi Suatu Pengantar, Cet. II Jakarta. PT Ideks.

Wandi, Didi., Adha, Suhroji dan Asriyah, Iyah. 2019. Pengaruh Komunikasi Terhadap Kinerja Pegawai Pada badan Penanggulangan Bencana Daerah (BPPD) Provinsi 
Banten. Jurnal Ekonomi Vokasi, Vol. 2 No. 2 Juni 2019, ISSN 2622-4240. Hal. 1830.

Wijaya, A.W. 2000. Ilmu Komumikasi Pengantar Studi. Jakarta. Rineka Cipta. 